DOI: $10.1515 /$ pof-2015-0015

VOLUME 7, ISSUE 3, 2015

ISSN: 2036-5438

\title{
Solidarity in the European Union in Times of Economic Crisis
}

by

\author{
Jerónimo Maillo* and Justo Corti*
}

Perspectives on Federalism, Vol. 7, issue 2, 2015 


\begin{abstract}
The present special issue of Perspectives on Federalism reflects on the nature and characteristics of solidarity within a supranational context, it explains what solidarity has meant so far in the EU, how much solidarity we had during the crisis, what type of solidarity is needed and how to build it. It focuses on the new economic governance and its solidarity mechanisms during and after the economic crisis but tackles other related fields such as its impact on services of general economic interest or the European budget, as well as other areas where solidarity is also discussed such as the free movement of persons.

This monographic issue has its origin in the International Conference "Solidarity in Hard Times. Solidarity and the European Social Model in times of economic crisis" organized by the University Institute for European Studies (IDEE) on 11-12 June 2015 in Madrid, within the Jean Monnet Network MoreEU ("More Europe to overcome the crisis").
\end{abstract}

Key-words

EU law, solidarity, supranational integration, new economic governance 
Solidarity has traditionally been at the core of the cohesion of modern European societies and of the legitimacy of our political systems. It is deeply rooted in the European identity, perceived by third parties as one of its distinctive features and often as one of its most worthwhile values. The so called 'European Social Model' is a crucial element to understand Europe's evolution since the second half of the XX century.

The European integration adventure has referred to solidarity since its very beginning when Robert Schuman stated that Europe would be built through concrete achievements which first create a 'de facto solidarity'. Mechanisms of solidarity (e.g. structural funds, cohesion funds, European Stability Mechanism, etc) had been key factors to accept new integration steps and maintain or increase the attractiveness of the European Union. The notion of solidarity is now contained in many provisions of the EU Treaties (e.g. article 3.5 TEU, for the external dimension, articles 2 and 42.7 TEU, and 122, 136 and 222, for the internal dimension) and includes solidarity among Member States, regions, citizens and generations. Both territorial and social cohesion are foreseen and pursued by many different policy tools.

However, the recent economic crisis has very harshly impacted in Europe, challenging and calling into question both solidarity between Members States and their citizens. The crisis has revealed serious weaknesses in the EU model of integration and, probably the worst, has put at risk the fragile European identity. Many had wrongly perceived that "Europe" was more part of the problem than part of the solution and this feeling led to increased support to Euroskeptic parties, both from the right and left, whose proposals for reducing the social impact of the crisis focused on "national" solutions.

Following an austerity-focused policy, underestimating the social impact of the crisis and the budget cuts of the periphery, Europe has given priority to win the battle of budget imbalances but risked to lose the war for European cohesion and citizens' legitimacy.

Beyond the economic crisis, political tensions between Member States have also arisen in other fields such as the refugees' crisis and free movement of persons within Europe. In all these fields, more solidarity has been claimed as a way forward to solve the crisis and to a certain extent it has been recognized as (at least) part of the solution. France has recently invoked by the very first time article 42.7 of the Treaty on the European Union concerning solidarity in defence in relation to the fight against jihadist terrorism after the Paris' attacks. 
However, what solidarity should mean, which intensity of increased solidarity, at which rhythm, and how the solidarity mechanisms should be built and worked, have generated disagreements and new tensions between Member States, political parties and public opinions.

We should nevertheless acknowledge that solidarity has existed in Europe in the latter years, that we have attained unprecedented levels of transfers and created new potential for solidarity within the European Union by very different and innovative means. We are every day more identifying common challenges, assuming common responsibilities to face these challenges and sharing the costs. For instance, regarding the economic crisis, aid in its different formats has amounted up to 500 billion euros and the European Central Bank's action has significantly supported national economies during the crisis; regarding free movement of persons, large numbers of EU citizens (particularly from the periphery) have found jobs in other European countries and most Member States have reached an agreement to fund and share the cost and the increasing number of refugees who are coming to Europe.

It is true that all these new solidary agreements have taken time, often too long time, and that they are not altruistic but often conditional and limited. We may discuss whether the solidarity level is sufficient, well designed and implemented and whether it should have been adopted more rapidly, we can even debate on the 'nature' of this solidarity tools, but it is undeniable that new solidarity mechanisms have been created and that solidarity has been part of the solution.

It is our personal belief that solidarity, more solidarity, is essential to maintain and further develop the process of European Integration. We need more Europe and more solidarity within the European Union. Solidarity is called to play a major role in the reconstruction and development of the European project. It could be crucial to reverse the current 'nationalistic' tensions and increase the sense of belonging of Europeans to Europe. Furthermore, it could open windows of opportunity to find European solutions to citizens' problems and therefore help Europe to face in common challenges and risks of the present and the future.

The difficulty lies in finding and consolidating a new architecture for this increased need of 'supranational or postnational solidarity'. We have to be innovative and find the 
right balance between the different interests at stake. We have to further develop solidarity between Member States, probably a different in nature solidarity, and explore new means of solidarity between citizens. We have to adjust solidarity to the supranational context, to the reinforced Union we need for the future.

The present monographic issue precisely discusses this topic though seven contributions that explains the nature of solidarity within a supranational context, what kind of solidarity we have had during the crisis and what we would need for the future, including the opportunities that offer solidarity mechanisms of the new economic governance, and other related areas where solidarity is discussed as services of general economic interest, the European budget or the free movement of persons.

Katerina Pantazatou examines the evolution of the EU 'redistributive' policies in the (post-) crisis EU era and inquires on whether the EU, faced with the recent unprecedented crisis has demonstrated a solidary spirit. She concludes that only "reciprocal solidarity" has been exhibited during the crisis. She argues that this type of solidarity is inherent in the EU by reason of the huge differences among the Member States and the lack of a common demos and ethos among the EU people and that the need of financial assistance programmes and the new economic governance were unfavorable environment for shifting to altruistic solidarity.

Francesco Nicoli's contribution challenges the view that any scheme of solidarity in the EU is self-defeating, inefficient and illegitimate. He explains the three main criticisms to European solidarity (the Myths of the Beggar, of the Efficient Markets and the Demos) and proposes a notion of "federative solidarity" providing a solution to the three "myths".

Mario Kölling searches for solidarity into the EU budget. He identifies a shift in the budget rationale, a trend from a national calculation of self-interests (richer EU countries helping poorer EU countries to compensate that the former obtain a larger return from market opening) towards an instrument to support policy programmes related to addressing common challenges. He argues that a reform of the own resources system and a stronger involvement of the European Parliament in the negotiation of the Multi-Annual Financial Framework would be essential to foster this trend. These reforms, together with an increase in the financial resources available, are necessary if the EU budget is to be 
reconciled with a solidarity role it should and has to play, in addition to giving the EU the means to properly address current and future challenges.

Marta Legnaioli evaluates the impact of austerity measures on national social protection mechanisms, in particular in Italy and Portugal. Within the process of 'Europeanization' of public services, she perceives the sovereign debt crisis as a new phase in this process, one that has not only limited the role of national social protection, but has even an impact on the definition of Services of General Economic Interest (SGEIs).

Arianna Vettorel focuses on the impact of the actions of the European Stability Mechanism (ESM) from a human rights perspective. She analyses to what extent the granting of financial assistance on the basis of strict conditionality measures has affected social rights in Europe and whether possible violations of human rights could be subject to traditional human rights mechanisms. She concludes that de iure is difficult and de facto unrealistic so that possible violations of human rights depending on conditionality measures are not likely to be remedied through the traditional legal channels.

Matteo de Nes examines the ESM Treaty and other relevant documents approved by its bodies (in particular the Code of Conduct and the By-Laws) through the lens of the transparency principle. He concludes that, within the ESM governance, confidentiality and secrecy are the rule and transparency and disclosure the exception, and he claims for higher standards of transparency.

Finally, Stefano Giubboni analyses the case-law of the European Court of Justice on the scope and limits of cross-border access of economically inactive Union citizens to national systems of social assistance. He focuses on the most recent case-law which shows, in his own words, "a spectacular retreat from the rhetoric of transnational solidarity in tune with the neo-nationalistic and social-chauvinistic moods prevailing in Europe”.

All these contributions were discussed during the International Conference "Solidarity in Hard Times. Solidarity and the European Social Model in times of economic crisis" organized by the University Institute for European Studies (IDEE), Jean Monnet Centre of Excellence at CEU San Pablo University, in the context of the network "More Europe to overcome the crisis" (Jean Monnet Network - 553614-EPP-1-2014-1-IT-EPPJMONETWORK) which was held on 11-12 June 2015 in Madrid, on the thirty anniversary of the signature of the EEC accession Treaty of Spain and Portugal. This enlargement is often 
considered to be the most successful from the perspective of solidarity. It is that spirit of solidarity that European leaders showed then that could become a source of inspiration to promote solidarity in the future.

The conference was part of the Jean Monnet Network MoreEU ("More Europe to overcome the crisis") led by Scuola Superiore Sant'Anna (Pisa) and comprising think tanks and research institutions of five European countries (Notre Europe - Jacques Delors Institute, CEU San Pablo Madrid; University of Warsaw and Nova Law School of Lisbon).

After the conference, selected papers were re-elaborated and presented for publication to Perspectives on Federalism. Once the peer-review was passed, this issue is the final outcome of the process. We are grateful to all the authors, the journal and its co-editors Roberto Castaldi and Giuseppe Martinico, the support granted by the European Commission through the Jean Monnet programme, and all the attendants to the conference who enrich the debate with their participation and comments. We all expect this issue to be a useful contribution to the debate on the present and future of the European Union, in particular to the role and design of solidarity within the European Union.

\footnotetext{
* Professor of EU Law and Senior Research Fellow at the Institute for European Studies of CEU San Pablo University, Madrid.

* Assistant Professor and Research Fellow at the Institute for European Studies of CEU San Pablo University, Madrid.
} 